\title{
Educational Game about Drugs for Visually Impaired People: A Comparison between Brazil and Portugal
}

\author{
Monaliza Ribeiro Mariano1, Lorita Marlena Freitag Pagliuca ${ }^{2}$, \\ Paula Marciana Pinheiro de Oliveira ${ }^{1}$, Paulo César de Almeida ${ }^{3}$, \\ Adriana Sousa Carvalho de Aguiar ${ }^{4}$, Wilson Correia de Abreu ${ }^{5}$
}

\author{
${ }^{1}$ Nursing Department, University of International Integration Lusophone African-Brazilian, Ceará, Brazil \\ ${ }^{2}$ Nursing Department, Senior Research, Federal University of Ceará, Ceará, Brazil \\ ${ }^{3}$ Nursing Department, State University of Ceará, Ceará, Brazil \\ ${ }^{4}$ Nursing Department, Faculty Integrated Grande Fortaleza, Fortaleza, Brazil \\ ${ }^{5}$ Nursing School of Porto, Porto, Portugal \\ Email: monalizamariano@unilab.edu.br, ‘pagliuca@ufc.br, pc2015almeida@gmail.com, \\ adrianaufc@gmail.com,wjabreu@esenf.pt
}

How to cite this paper: Mariano, M.R. Pagliuca, L.M.F., de Oliveira, P.M.P., de Almeida, P.C., de Aguiar, A.S.C. and de Abreu, W.C. (2017) Educational Game about Drugs for Visually Impaired People: A Comparison between Brazil and Portugal. Open Journal of Nursing, 7, 399-408. https://doi.org/10.4236/ojn.2017.73031

Received: February 9, 2017

Accepted: March 28, 2017

Published: March 31, 2017

Copyright $\odot 2017$ by authors and Scientific Research Publishing Inc. This work is licensed under the Creative Commons Attribution International License (CC BY 4.0).

http://creativecommons.org/licenses/by/4.0/

\begin{abstract}
Objective: To validate the educational board game "Drugs: playing fair" for visually impaired people in Brazil and Portugal. Methods: Study of apparent validation carried out in two associations for visually impaired people in Fortaleza, Brazil, and in Porto, Portugal. Thirty-six visually impaired people, 18 from each country, participated in the study. An evaluation tool with 23 items on specifications, content and motivation of the game was applied. Results: The scores awarded in both countries were excellent, with means varying in Brazil from 9.0 to 9.6 and in Portugal, from 8.4 to 9.2. As for the categories and subcategories, the best means in Brazil were: content (9.5); theoretical and methodological consistency (9.6) and concepts/information (9.5). In Portugal, the best means were concepts/information (9.2) and curiosity (9.2). Only two items showed a significant difference: "it allows interaction" $(p=0.024)$ and "compatible degree of difficulty" ( $p=0.012$ ). Conclusion: The educational game on drugs was validated in Brazil and Portugal.
\end{abstract}

\section{Keywords}

Validation Studies, Health Promotion, Play and Playthings, Nursing, Visually Impaired Persons

\section{Introduction}

The society experiences a public health problem in relation to the abuse of drugs 
because new drugs are created and consumed by individuals increasingly younger. There is evidence of use of illicit drugs by college students, accounting for approximately $50 \%$ of the high-risk group [1]. Half of the students had used an illicit drug, such as cocaine, or had intake of alcohol, at least once in life [2]. Alcohol is considered a licit drug and is among the substances associated with high mortality rates due to road accidents [3].

Considering this problem and considering that the use of drugs does not depend on race, color, sex, age, and social status, activities of intervention, prevention or rehabilitation are very important, including all areas of society because any individual has the right for health and information. Thus, Visually Impaired People (VIP) who represent a considerable portion of the population should be included in this process. The last census conducted in Brazil showed that this group represented a total of 35 million people, of whom 500,000 are blind [4]. In Portugal, they were 163,515 individuals, representing $9.16 \%$ of the population [5].

These individuals make use of alcohol and are also vulnerable to drug abuse, and, therefore, it is necessary to inform this clientele in order to promote health and prevent and/or reduce the consumption of drugs, especially when there is consumption of licit drugs such as alcohol [6].

In order to achieve health promotion, it is necessary to understand the peculiarities that this clientele has, as the limited or absent sight. Resources and services that may allow decisions on their health should, therefore, be developed and used. Among these materials, there are recreational resources such as educational games intended to promote health education. However, among the artifacts that are intended for this clientele, few are directed to education on health promotion and comply with the characteristics of assistive technologies [7]. Thus, games should be accessible in order to carry out effective and efficient health promotion, capable of generating learning and promoting dialogue. To make these resources available to the public, it is essential that they be assessed and validated. In this way, reliable products with real possible impacts on health promotion may be obtained.

Because Brazil and Portugal have problems related to drug abuse and because we are aware of the importance of materials adapted for health promotion, a game about drugs [8] was developed, with content validated [9] and evaluated for effectiveness regarding the accessibility of information to people with visual impairment [10].

"Drugs: playing fair" consists in a board game with unidirectional path formed by houses with different textures, letters containing questions and answers, pins, chips and game instructions, and it is played in pairs. It contains information about definition and classification of drugs, the main signs and symptoms, protective factors and risk. The game is in Braille and ink with large typing.

The present study aimed to validate this educational game with Visually Impaired People in Brazil and Portugal.

\section{Methods}

Study of apparent validation carried out with the objective to prevent that the con- 
struct be too primitive for these subjects and show the degree to which instrument measures what it should measure. There are three types of validation: of the content, criterion and of the construct. In this case, the validity refers to the construct "educational game" [11]. The analysis of results verifies if the objectives were achieved.

The study was conducted in two associations to VIP, one in the city of Fortaleza in Brazil and the second in Porto, in Portugal. The sample was by convenience, which entails the use of people that are more conveniently available to participate in the study. The defined inclusion criteria were ability to read in Braille or capital letters and be motivated for the game, without age restriction. Those who could not read braille or capital letters, who were unmotivated for the game, which found it difficult to understand the rules of the game or did not sign a free and informed consent were excluded. The participants were recruited from Schools and Associations for the Blind Specialized Services and, after participating in the experience with the educational game, they were asked to name other persons interested in participating.

Data collection was performed between the months of December 2012 and February 2013 in Brazil, and from April through June 2013 in Portugal. For data collection, an instrument for evaluation of the educational game on drugs was applied [12]. The instrument was answered individually. The tool included items that questioned whether the game fulfilled the educational function; the specificities with regard to mechanics and functionality; the content in matter of accessibility, theoretical methodological consistency, concepts and information; the level of motivation to evaluate challenge, fantasy, curiosity and interpersonal motivation. Responses were given on a scale of 0 to 10 .

At the start of data collection, pairs were formed and the purpose of the research was explained. Then, the players received the board game. The rules of the game were made available in Braille, audio or were read aloud by the researcher. In the sequence, the game was started by touch and reading of the cards, without interference of the researcher. When the game ended, the evaluation tool was applied. The tool contained 23 items related to specifications, content and motivation of the game. The category Game Specifications are related to its applicability, if it is easy to handle and if its structure allows the individual to recognize its components. In turn, the category Content refers to the accessibility of information covered, concepts and information contained, and if there is consistency between what is stated in the cards and the theme drugs associated with the relevance of the approach. The category Motivation considers the individual's motivation to learn by inserting levels of difficulty to the questions, cognitive curiosity, as well as aspects that surprise and/or intrigue the individual.

Inclusion criteria were: being visually impaired person who read braille or can read enlarged letters. There were no restrictions regarding age, gender and level of education.

Results were organized in tables and normality and equality of variances of data were checked thorugh Kolmogorov-Smirnov and Levene tests and then the means 
of the instrument between the two countries were analyzed through t-Student test. Analysis with $p<0.05$ was considered statistically significant. Data were processed in SPSS 20.0.

The research was approved by the Ethics Committee of the Federal University of Ceará under Opinion $n^{\circ} 115,850$. The study adhered to national and international standards of ethics in research involving humans.

\section{Results}

The study included 36 VIP, 18 from each country. It was found that the average age of Portugal (49.8) was higher than Brazil (29.1) $(p<0.0001)$. Regarding education level, the average number of years of study were similar $(p=0.054)$, but higher in Brazil (10.9 years) than in Portugal (9 years).

Table 1 shows the mean and standard deviation of categories and subcategories, comparing Brazil and Portugal.

Clearly, there was a statistical difference between Brazil and Portugal in the subcategory challenges, which received a better assessment by the Brazilian players. The following table shows the ratings of the two countries for the items of the present instrument (Table 2).

There was a statistically significant difference in "it allows interaction" ( $p=$ $0.024)$ and "compatible degree of difficulty" $(p=0.012)$. There was a difference in interaction and degree of difficulty to play the game in these items. In Brazil, the participants felt that the game allows for greater interaction and they had less difficulty in using the game.

Table 1. Game assessment according to categories and subcategories of the scores awarded by people with impaired vision in Brazil and Portugal, Ceará, Brazil, 2014.

\begin{tabular}{cccc}
\hline Categories/subcategories & $\begin{array}{c}\text { Mean } \pm \mathrm{SD}^{*} \\
\text { Brazil }\end{array}$ & $\begin{array}{c}\text { Mean } \pm \mathrm{SD} \\
\text { Portugal }\end{array}$ & $p$ \\
\hline Educational game & $9.3 \pm 0.7$ & $8.8 \pm 1.3$ & 0.219 \\
Game specifications & $9.0 \pm 1.0$ & $8.5 \pm 1.7$ & 0.255 \\
Game mechanics & $9.1 \pm 1.2$ & $8.4 \pm 1.8$ & 0.183 \\
Functionality & $9.0 \pm 1.2$ & $8.6 \pm 1.8$ & 0.445 \\
Content & $9.5 \pm 0.8$ & $8.9 \pm 1.2$ & 0.112 \\
Accessibility & $9.2 \pm 1.3$ & $8.5 \pm 1.6$ & 0.134 \\
Theoretical/methodological consistency & $9.6 \pm 0.8$ & $9.0 \pm 1.2$ & 0.084 \\
Concepts/information & $9.5 \pm 0.9$ & $9.2 \pm 1.4$ & 0.442 \\
Motivation & $9.2 \pm 0.7$ & $8.9 \pm 1.3$ & 0.352 \\
Challenges & $9.2 \pm 0.8$ & $8.4 \pm 1.3$ & 0.041 \\
Fantasy & $9.2 \pm 0.8$ & $9.0 \pm 1.3$ & 0.468 \\
Curiosity & $9.0 \pm 1.3$ & $9.2 \pm 1.5$ & 0.678 \\
Interpersonal motivation & $9.3 \pm 0.8$ & $9.0 \pm 1.5$ & 0.416 \\
\hline
\end{tabular}

${ }^{*} \mathrm{SD}=$ Standard Deviation. 
Table 2. Comparison between Brazil and Portugal scores for the items in the assessment of the game, Ceará, Brazil, 2014.

\begin{tabular}{|c|c|c|c|}
\hline Questions & $\begin{array}{c}\text { Mean } \pm \text { SD } \\
\text { Brazil }\end{array}$ & $\begin{array}{c}\text { Mean } \pm \text { SD } \\
\text { Portugal }\end{array}$ & $p$ \\
\hline Clear instructions & $9.2 \pm 1.5$ & $8.1 \pm 2.0$ & 0.074 \\
\hline Comprehensible instructions & $9.1 \pm 1.2$ & $8.8 \pm 1.7$ & 0.581 \\
\hline Recognizable components & $8.6 \pm 1.6$ & $8.6 \pm 1.8$ & 0.923 \\
\hline Manipulable components & $9.3 \pm 1.1$ & $8.6 \pm 1.9$ & 0.183 \\
\hline Understandable language & $9.1 \pm 1.8$ & $8.3 \pm 1.8$ & 0.247 \\
\hline Understandable components & $9.4 \pm 0.9$ & $8.7 \pm 1.9$ & 0.129 \\
\hline It allows interaction & $9.8 \pm 0.5$ & $8.9 \pm 1.4$ & 0.024 \\
\hline It enables discussion/reflection & $9.6 \pm 0.9$ & $9.1 \pm 1.5$ & 0.248 \\
\hline It builds knowledge & $9.4 \pm 1.1$ & $8.9 \pm 1.7$ & 0.308 \\
\hline Subject is coherent and contextualized & $9.4 \pm 1.0$ & $9.2 \pm 1.3$ & 0.584 \\
\hline Information is relevant & $9.5 \pm 1.0$ & $9.1 \pm 1.5$ & 0.362 \\
\hline Challenges are exciting & $9.2 \pm 1.5$ & $8.6 \pm 1.9$ & 0.295 \\
\hline Degree of difficulty is compatible & $9.3 \pm 0.8$ & $8.2 \pm 1.5$ & 0.012 \\
\hline It provides dynamic learning & $9.2 \pm 1.0$ & $8.5 \pm 1.5$ & 0.105 \\
\hline Comparisons facilitate understanding & $9.2 \pm 1.3$ & $8.7 \pm 1.6$ & 0.312 \\
\hline It stimulates imagination & $9.3 \pm 1.0$ & $9.2 \pm 1.3$ & 0.890 \\
\hline It brings benefit to the everyday life & $9.2 \pm 1.1$ & $9.0 \pm 1.4$ & 0.597 \\
\hline It arouses curiosity & $9.1 \pm 1.4$ & $9.2 \pm 1.5$ & 0.737 \\
\hline Interest in playing is maintained & $9.1 \pm 1.3$ & $9.3 \pm 1.5$ & 0.632 \\
\hline Competitiveness enhances self-esteem & $8.6 \pm 1.4$ & $8.6 \pm 1.7$ & 0.914 \\
\hline Successes and mistakes encourage learning & $9.3 \pm 1.0$ & $8.8 \pm 1.6$ & 0.323 \\
\hline I would play it again & $9.7 \pm 0.9$ & $9.3 \pm 1.6$ & 0.392 \\
\hline I would indicate it to someone else & $9.8 \pm 0.7$ & $9.3 \pm 1.7$ & 0.203 \\
\hline
\end{tabular}

\section{Discussion}

The main results related to the profile of the subjects include the findings that there is a statistically significant difference with respect to age between Brazil and Portugal. The oldest population was found in Portugal; although statistics describe that population aging is a worldwide phenomenon.

Data from census show that, in Portugal, the elderly population, defined as people aged over 65 years has steadily increased. In 2001, this population accounted for about $16.5 \%$ of the total population, and increased to $19.9 \%$ in 2013 , with a greater proportion of women. It is estimated that elderly people living in Portugal exceeded 2 million. This made Portugal the fourth country with the highest proportion of old people in 2013 [5].

When this is compared to Brazil, it is clear also that the aging process of the population in this country is identified by the narrowing of the base and expan- 
sion of the top of the age pyramid. This directly influences the population aging index and this is currently happening as a result of the decline in fertility and reduced mortality [13]. In this research, despite the aging process is noticeable in both countries, the largest number of elderly was found in Portugal. Literature describes that students in this country have sought to study and work in other countries, and this attitude has become considerably more frequent since the early twenty-first century. As a consequence, this may have contributed to the high proportion of elderly people found there [14].

Among the subjects of the two countries, there was no difference in the education level, which corresponded predominantly to primary or secondary incomplete education. The Demographic Census shows significant differences between level of education of people with and without disabilities. Most of the population aged at 15 years or older that have disabilities have no education or have incomplete primary $(61.1 \%)$ education compared with those people who have no disabilities (38.2\%) [13]. Therefore, individuals with disabilities have no schooling or a few years of schooling.

Participants showed satisfaction in relation to the educational game. In Brazil, all scores were above 9.0 and in Portugal, these were greater than 8.4.

Challenge, characterized as antagonistic element to the action of the player that helps in attaining the game's goals, achieved significant results $(p=0.041)$. This element is intended to ensure an additional motivating factor for achieving the set goals. When these are achieved, appropriate rewards are given, such as points and items of the game [15].

Games, in their educational potential, generate in players the predisposition to learn, since situations of challenges (exploration, discovery of rules, strategizing) are created, and encourage the use of logical reasoning to solve problems. Thus, the use of games in education favors the development of logic, strategy, analysis and sometimes memory, starting from trial and error to win the stages of the game. The game also encourages learning exposed in situations and in the context in which it is involved [16].

The best assessments were obtained in the categories content and motivation. Content refers to the theme, that is, the psychoactive drugs. This theme currently affects millions of people.

Thus, the relevance and the work that may reinforce the approach of the importance of avoiding the use of these drugs and reduce or eliminate their comsumptuion by those people who are already making use of such drugs, are of paramount relevance.

Motivation and challenge inherent to the game contribute for its value to education because solving problems stimulates the basic skills and help developing superior skills [17]. The theme, drugs, is motivating and represents a challenge because of the doubts that the subjects have on the subject. For a game to be useful in the educational process, this should promote situations that awaken the interest and challenge the participant to solve problems, as well as that allow the person to make a self-assessment regarding the performance, provided the per- 
son actively participates in all stages.

Concerning the assessment of the instrument items, only two out of the 23 items showed significant difference: "it allows interaction" $(p=0.024)$ and "compatible degree of difficulty" ( $p=0.012)$. This means that, although with excellent evaluations, both countries had a different perception of the game. This may be related to the habit of Brazilian participants in this study to have a mean age (29.1) below the Portuguese (49.8), and use play materials or educational board games, having perhaps more interest and ease to handle the game, ultimately reflecting the allocation of higher scores to these items.

Allow interaction when people are playing is essential. When the game allows learning and promotes health, this further enhances its content and its usefulness. Dialogue is critical here, to allow exchange of information and consequently exchange of knowledge [16].

Although it is a course game, "Drugs: Playing Fair" also showed characteristics of cooperative games to open space for interaction and assistance between the players, which take precedence over the objective of winning the game. It was possible to gather in the game features such as cooperation, acceptance, involvement and fun.

Regarding the item "compatible degree of difficulty", although groups had different evaluations, it is interesting to note that the level of education did not contribute to significant differences. Thus, this finding may be associated with the fact that the content was considered difficult. This calls for the importance of interventions related to drugs, including on the part of health professionals.

The discussion on drugs should not be restricted to schools and universities, as this topic it permeates the various spheres of society. However, the debate that is carried out in schools on various topics including drugs as a manner to promote prevention and early intervention is important. The school is the gateway to adulthood [18]. However, few institutions of higher education have systematic approaches to prevent or reduce drug use [19]. Regarding the assessment of the presented game, the items "I would play it again" $(9.7,9.3)$ and "I would indicate it to another person" $(9.8,9.3)$ stood out. The highest scores were attributed to these items by both Brazilian and Portuguese participants. This demonstrates that the game is a useful tool and has good receptivity. Among the different methodologies that can be used in educational practices are those with playful character. The playful atmosphere of the games facilitates the acquisition of knowledge in a pleasant way.

The playfulness is important in all age groups, because besides the fun, it provides the process of knowledge construction, and it is one of the possible mediators of the learning process [20].

In addition to these items, others also stood out due to excellent scores awarded by the Brazilian participants, "it enables discussion/reflection" (9.6) and "relevant information" (9.5). This shows that the game favored the implementation of the learning process and mediated the link between information, discussion and reflection. Participants were able to fill gaps of knowledge, clarify doubts and reflect on the subject proposed by the game, namely, drugs and their effects. 
Therefore, the game in its pedagogical aspect allows the participant to develop the ability to think, reflect, analyze, understand, make hypotheses, test them and evaluate them with autonomy and cooperation [8].

Portuguese participants valued the items "interest in playing is maintained" (9.3), "it arouses curiosity" (9.2) and "it stimulates imagination" (9.2). The game "Drugs: Playing Fair" fires the imagination by putting the participant in situations that are similar to reality, so as to promote their immersion in the context of the game. This stimulates curiosity, leaving the player motivated to advance to the following stages of the game.

On the results presented, it is emphasized, therefore, the importance of the use and application of games as an educational strategy for health. A steady increase has been observed in the production of these types of games. However, few are those designed aiming at people with disabilities.

In terms of the current scenario of technological innovations in health, a portion of the population still lives with difficulty to access educational games. In the case of persons with disabilities, particularly visual impairment, accessibility to services and information is often limited. In this context, health promotion strategies are compromised because this population is left with no choice to decide about their health, particularly when they are on the agenda to discuss sensitive issues in the family and at school, as it is the case of drugs.

One limitation of the study was the small number of people motivated to participate in the study. Board games are not regularly available to this audience. Additional efforts from researchers were made to bring blind people to engage in this innovation. It was difficult to prepare the logistics to locate people interested in the game and theme, to find a suitable place and time for two people to play, and finally to gather them to play. All this planning required energy and dedication. We strongly believe that a growing number of these specific types of games will increase interest from researchers and participants.

Thus, health education is relevant in this context. This consists currently in a multifaceted field. When analyzed from the perspective of health promotion, it denotes more than passing on information and inducing certain behaviors [7], as it is proposed by the educational game. It includes also support the people and the community, so that they may make their own analysis and become able to make their own decisions, developing critical awareness [21].

\section{Conclusions}

The educational game "Drugs: Playing Fair" was validated in Brazil and Portugal. In the evaluation of the game, score was attributed so that means varied in Brazil from 9.0 to 9.6, and Portugal, from 8.4 to 9.2. As for the categories and subcategories, the highest means in Brazil were obtained for: content $(9,5)$; theoretical and methodological consistency (9.6) and concepts/information (9.5). In Portugal, the highest means were obtained for concepts/information (9.2) and curiosity (9.2).

The game sparked interest and curiosity, sharpening the desire to discover the 
content of the cards and the dynamics of the game in itself. Still, interaction between players was observed, as well as discussion of views, enabling acquisition of information and discussion of the topic.

The number of participants was the main limitation of the study, especially due to the difficulty of gathering, physically, two visually impaired people for the application of the game.

The adapted tactile educational game appears as a possibility of teaching and learning, enabling such clients to access information to aid them to decide on their health. This resource is low cost and traditional and can be used by professionals of both areas of health and education.

\section{References}

[1] U.S. Department of Health and Human Services (2010) Substance Abuse and Mental Health Services Administration. Results from the 2009 National Survey on Drug Use and Health. Summary of National Findings. http://www.gmhc.org/files/editor/file/a_pa_nat_drug_use_survey.pdf

[2] Andrade, A.G., Duarte, P.C.A.V., Barroso, L.P., Nishimura, R., Alberghini, D.G. and Oliveira, L.G. (2012) Use of Alcohol and Other Drugs among Brazilian College Students: Effects of Gender and Age. Revista Brasileira de Psiquiatria, 34, 294-305. http://www.scielo.br/scielo.php?script=sci_arttext\&pid=S1516-44462012000300009

[3] Callaghan, R.C., Gatley, J.M., Veldhuizen, S., Lev-Ran, S., Mann, R. and Asbridge, M. (2013) Alcohol or Drug Use Disorders and Motor Vehicle Accident Mortality: A Retrospective Cohort Study. Accident Analysis \& Prevention, 53, 149-155. http://www.sciencedirect.com/science/article/pii/S0001457513000213 https://doi.org/10.1016/j.aap.2013.01.008

[4] Ministry of Health (2008) National Policy on the Health of Persons with Disabilities. Ministry of Health, Brasília.

[5] Carrilho, M.J. and Craveiro, M.L. (2014) Statistics Portugal the Recent Demographic Situation in Portugal.

http://www.ine.pt/xportal/xmain?xpid=INE\&xpgid=ine_publicacoes\&PUBLICACO ESpub_boui $=210786633 \&$ PUBLICACOESmodo $=2$

[6] Silva, S.E.D., Padilha, M.I.C.S. and Santos, L.M.S. (2011) A enfermagem estimulando o autocuidado de adolescentes a partir das representações sociais desses sobre as bebidas alcoólicas (Nursing Encouraging Self-Care for the Teens from Social Representations of These on Alcoholic Beverages). Enfermagem em Foco, 2, 160-163. http://revista.portalcofen.gov.br/index.php/enfermagem/article/view/125

[7] Mariano, M.R., Pinheiro, A.K.B., Aquino, O.S., Ximenes, L.B. and Pagliuca, L.M.F. (2013) Jogo educativo na promoção da saúde de adolescentes: Revisão integrativa (Educational Games to Promote Adolescent Health: An Integrative Review). Revista Eletrônica de Enfermagem, 15, 265-273. https://www.fen.ufg.br/fen_revista/v15/n1/pdf/v15n1a30.pdf

[8] Mariano, M.R., Rebouças, C.B.A. and Pagliuca, L.M.F. (2013) Educative Game on Drugs for Blind Individuals: Development and Assessment. Revista da Escola de Enfermagem da USP, 47, 930-936.

http://www.scielo.br/scielo.php?pid=S0080-62342013000400930\&script=sci_arttext \&tlng=en https://doi.org/10.1590/S0080-623420130000400022

[9] Cezario, K.G. and Pagliuca, L.M.F. (2007) Assistive Health Technology for the Blind People: A Focus on Drugs Prevention. Escola Anna Nery, 11, 677-681. http://www.scielo.br/scielo.php?script=sci_arttext\&pid=S1414-81452007000400019 
[10] Mariano, M.R., Pagliuca, L.M.F., Almeida, P.C. and Abreu, W.C. (2014) Visually Impaired Individuals in Brazil and Portugal and Learning about Drugs through a Board Game. Open Journal of Nursing, 4, 677-682.

http://www.scirp.org/journal/PaperInformation.aspx?PaperID=49667 https://doi.org/10.4236/ojn.2014.410072

[11] Sampieri, R.H., Collado, C.F. and Lúcio, M.P.B. (2013) Metodologia de pesquisa (Research Methodology). AMGH, Brazil.

[12] Mariano, M.R., Guimaraes, F.J. and Pagliuca, L.M.F. (2016) Construction and Evaluation of Issues Database about Psychoactive Substances. Revista de Enfermagem UFPE, 10, 680-685.

http://www.revista.ufpe.br/revistaenfermagem/index.php/revista/article/viewArticle $\underline{19052}$

[13] Brazilian Institute of Geography and Statistics (2011) Demographic Census 2010: Population and Households Characteristics: Universe Results IBGE, Brazil.

[14] Organization for Economic Co-Operation and Development (2013) Education at a Glance 2013. http://dx.doi.org/10.1787/eag-2013-en

[15] Barcelos, T.S., Carvalho, T., Schimiguel, J. and Silveira, I.F. (2011) Análise comparativa de heurísticas para avaliação de jogos digitais (Comparative Analysis of Heuristics for Digital Game Evaluation). Proceedings of the 10 th Brazilian Symposium on Human Factors in Computing Systems and the 5 th Latin American Conference on Human-Computer Interaction, Porto de Galinhas, 25-28 October 2011, 187-196.

[16] Yonekura, T. and Soares, C.B. (2010) The Educative Game as a Sensitization Strategy for the Collection of Data with Adolescents. Revista Latino-Americana de Enfermagem, 18, 968-974.

http://www.scielo.br/scielo.php?script=sci_arttext\&pid=S0104-11692010000500018 https://doi.org/10.1590/S0104-11692010000500018

[17] Santos, S.M.P. (2010) Os jogos, brinquedos e dinâmicas (Games, Toys and Dynamics). In: Santos, S.M.P., Ed., O brincar na escola-Metodologia lúdicavivencial, coletânea de jogos, brinquedos e dinâmicas. (Playing at School-Playful-Experience Methodology, Compilation of Games, Toys and Dynamics), Vozes, Brazil.

[18] Malta, D.C., Mascarenhas, M.D.M., Porto, D.L., Duarte, E.A., Sardinha, L.M., Barreto, S.M. and Morais Neto, O.L. (2011) Prevalence of Alcohol and Drug Consumption among Adolescents: Data Analysis of the National Survey of School Health. Revista Brasileira de Epidemiologia, 14, 136-146. http://www.scielo.br/pdf/rbepid/v14s1/en_a14v14s1.pdf

[19] Dennhardt, A.A. and Murphy, J.G. (2013) Prevention and Treatment of College Student Drug Use: A Review of the Literature. Addictive Behaviors, 38, 2607-2618. http://www.sciencedirect.com/science/article/pii/S0306460313001664 https://doi.org/10.1016/j.addbeh.2013.06.006

[20] Silva, J.M., Pagliuca, L.M.F., Carvalho, A.T., Oliveira, M.G. and Almeida, P.C. (2015) Schoolchildren's Knowledge about Disabled People: Labyrinth Game in Health Promotion. Revista de Enfermagem da UERJ, 23, 254-259.

http://www.e-publicacoes.uerj.br/index.php/enfermagemuerj/article/view/10611/18 246

[21] Oliveira, M.S., Santos, M.C.L., Almeida, P.L., Panobianco, M.S. and Fernandes, A.F.C. (2012) Evaluation of an Educational Handbook as a Knowledge-Acquisition Strategy for Mastectomized Women. Revista Latino-Americana de Enfermagem, 20, 668-676.

http://www.scielo.br/scielo.php?script=sci_arttext\&pid=S0104-11692012000400006 https://doi.org/10.1590/s0104-11692012000400006 
Submit or recommend next manuscript to SCIRP and we will provide best service for you:

Accepting pre-submission inquiries through Email, Facebook, LinkedIn, Twitter, etc. A wide selection of journals (inclusive of 9 subjects, more than 200 journals)

Providing 24-hour high-quality service

User-friendly online submission system

Fair and swift peer-review system

Efficient typesetting and proofreading procedure

Display of the result of downloads and visits, as well as the number of cited articles Maximum dissemination of your research work

Submit your manuscript at: http://papersubmission.scirp.org/

Or contact ojn@scirp.org 